…………………

Vertebrate Genomes 


\section{Genome Dynamics}

\section{Vol. 2}

Series Editor

Jean-Nicolas Volff Würzburg

Executive Editor

Michael Schmid Würzburg

Advisory Board

John F.Y. Brookfield Nottingham

Jürgen Brosius Münster

Pierre Capy Gif-sur-Yvette

Brian Charlesworth Edinburgh

Bernard Decaris Vandoeuvre-lès-Nancy

Evan Eichler Seattle,WA

John McDonald Atlanta, GA

Axel Meyer Konstanz

Manfred Schartl Würzburg

\section{KARGER}




\section{Vertebrate Genomes}

Volume Editor

Jean-Nicolas Volff Würzburg

32 figures, 21 in color, and 11 tables, 2006

KARGER $\quad \begin{aligned} & \text { Basel } \cdot \text { Freiburg } \cdot \text { Paris } \cdot \text { London } \cdot \text { New York } \cdot \\ & \text { Bangalore } \cdot \text { Bangkok } \cdot \text { Singapore } \cdot \text { Tokyo } \cdot \text { Sydney }\end{aligned}$ 


\section{Jean-Nicolas Volff \\ Biofuture Research Group 'Evolutionary Fish Genomics' \\ Physiologische Chemie 1 \\ Biozentrum, University of Würzburg \\ Am Hubland \\ D-97074 Würzburg}

Library of Congress Cataloging-in-Publication Data

Vertebrate genomes / volume editor, Jean-Nicolas Volff.

p. ; cm. - (Genome dynamics, ISSN 1660-9263 ; v. 2)

Includes bibliographical references and index.

ISBN-13: 978-3-8055-8151-6 (hardcover : alk. paper)

ISBN-10: 3-8055-8151-3 (hardcover : alk. paper)

1. Genomes. 2. Genetics. 3. Vertebrates-Genetic aspects. I. Volff,

Jean-Nicolas. II. Series.

[DNLM: 1. Genome. 2. Genomics. 3. Vertebrates-genetics. QU 470 V567 2006]

QH447.V47 2006

$572.8^{\prime} 616-\mathrm{dc} 22$

2006016490

Bibliographic Indices. This publication is listed in bibliographic services, including Current Contents ${ }^{\mathbb{R}}$ and Index Medicus.

Disclaimer. The statements, options and data contained in this publication are solely those of the individual authors and contributors and not of the publisher and the editor(s). The appearance of advertisements in the book is not a warranty, endorsement, or approval of the products or services advertised or of their effectiveness, quality or safety. The publisher and the editor(s) disclaim responsibility for any injury to persons or property resulting from any ideas, methods, instructions or products referred to in the content or advertisements.

Drug Dosage. The authors and the publisher have exerted every effort to ensure that drug selection and dosage set forth in this text are in accord with current recommendations and practice at the time of publication. However, in view of ongoing research, changes in government regulations, and the constant flow of information relating to drug therapy and drug reactions, the reader is urged to check the package insert for each drug for any change in indications and dosage and for added warnings and precautions. This is particularly important when the recommended agent is a new and/or infrequently employed drug.

All rights reserved. No part of this publication may be translated into other languages, reproduced or utilized in any form or by any means electronic or mechanical, including photocopying, recording, microcopying, or by any information storage and retrieval system, without permission in writing from the publisher.

(C) Copyright 2006 by S. Karger AG, P.O. Box, CH-4009 Basel (Switzerland)

www.karger.com

Printed in Switzerland on acid-free paper by Reinhardt Druck, Basel

ISSN 1660-9263

ISBN-10: 3-8055-8151-3

ISBN-13: 978-3-8055-8151-6 


\section{Contents}

\section{Preface}

1 The Human Genome and Its Upcoming Dynamics Platzer, M. (Jena)

17 Primate Genomes

Herlyn, H.; Zischler, H. (Mainz)

\section{The Mouse Genome}

Brown, S.D.M.; Hancock, J.M. (Harwell)

\section{The Dog Genome}

Galibert, F.; André, C. (Rennes)

\section{The Feline Genome}

Murphy, W.J. (College Station, Tex.)

\section{The Bovine Genome}

Womack, J.E. (College Station, Tex.)

79 The Sheep Genome Cockett, N.E. (Logan, Utah)

86 Cracking the Genomic Piggy Bank: Identifying Secrets of the Pig Genome Mote, B.E.; Rothschild, M.F. (Ames, Iowa) 
97 The Horse Genome

Chowdhary, B.P.; Raudsepp, T. (College Station, Tex.)

111 Marsupial and Monotreme Genomes

Koina, E.; Fong, J.; Marshall Graves, J.A. (Canberra)

123 The Chicken Genome

Burt, D.W. (Edinburgh)

138 Insights from Xenopus Genomes

Pollet, N.; Mazabraud, A. (Orsay)

154 The Tetraodon Genome

Roest Crollius, H. (Paris)

165 The Medaka Genome: Why We Need Multiple Fish

Models in Vertebrate Functional Genomics

Mitani, H. (Chiba); Kamei, Y. (Kyoto); Fukamachi, S.; Oda, S. (Chiba);

Sasaki, T.; Asakawa, S. (Tokyo); Todo, T. (Kyoto); Shimizu, N. (Tokyo)

183 The Zebrafish Genome: A Review and msx Gene Case Study

Postlethwait, J.H. (Eugene, Oreg.)

198 Urochordate Genomes

Satoh, N.; Kawashima, T.; Shoguchi, E.; Satou, Y. (Kyoto)

213 Author Index

214 Subject Index 


\section{Preface}

The second volume of 'Genome Dynamics' is dedicated to 'Vertebrate Genomes'. The publication of the first draft of the human genome five years ago has opened a new era of vertebrate comparative genomics. Now genome draft sequences for chimpanzee, mouse, rat, dog, chicken as well as for several fish species are available for the reconstruction of the evolutionary history of vertebrate genomes during the last 450 millions of years. Several other important projects are underway and draft sequences will be available for additional vertebrate species in the next future.

Because Genomics is a fast moving science, it is not easy for the nonspecialist to get an overview on the current knowledge on vertebrate genomes. Therefore, this volume of 'Genome Dynamics' aims to present a timely update on the past, present and future of major vertebrate genome projects. Within 16 chapters, reputed specialists provide short but informative reviews on the current status of mammalian, bird, amphibian and fish genomics. As it is the rule in evolutionary analyses, an 'outgroup' is even provided, under the form of a chapter on urochordate genomes. The reader will also find in this book a useful overview on resources available for each genome, as well as a description of the medical and economical perspectives opened by the different projects.

All papers published in Genome Dynamics are reviewed according to classical standards. I would like to thank all contributors and referees involved in this book, Dr. Michael Schmid and his team, as well as Karger Publishers for their invaluable help during the preparation of this volume.

Jean-Nicolas Volff

Würzburg, April 2006 
